\title{
STUDI KECELAKAAN KERJA OPERATOR MESIN DI INDUSTRI PENGOLAHAN KELAPA SAWIT: INVESTIGASI DAN ANALISIS PENYEBAB DENGAN METODE 5 WHYS DAN SCAT
}

\author{
Luciana Triani Dewi' ${ }^{1}$, Lucy Versyanti Pangaribuan² \\ Program Studi Teknik Industri, Fakultas Teknologi Industri, Universitas Atma Jaya Yogyakarta \\ Jl. Babarsari No. 43 Yogyakarta \\ Email: triani.dewi@uajy.ac.id, lucypangaribuan@gmail.com
}

\begin{abstract}
ABSTRAK
Kecelakaan kerja akibat mesin merupakan kejadian yang sering kali terjadi pada industri, termasuk industri pengolahan kelapa sawit. Pencegahan kecelakaan akibat permesinan dapat dilakukan melalui pendekatan antisipasi bahaya dengan belajar dari kasus yang telah terjadi sebelumnya dan melakukan tindakan pengendalian. Penelitian terdahulu terkait kecelakaan kerja di industri pengolahan kelapa sawit lebih bersifat umum untuk menemukan penyebab dan pengendaliannya. Metode yang umum digunakan adalah analisis postur kerja, evaluasi ergonomi, dan identifikasi bahaya. Penelitian ini fokus menganalisis kasus kejadian kecelakaan kerja pada operator mesin kapstan di industri pengolahan kelapa sawit yang berakibat fatal yaitu kematian. Sejauh ini belum ditemukan publikasi penelitian tentang kecelakaan akibat mesin ini. Studi yang dilakukan bersifat deskriptif analitis dengan menelaah kasus kejadian kecelakaan kerja mesin kapstan untuk menemukan akar masalah dan memberikan solusi. Teknik yang digunakan adalah 5 whys dan Sytematic Cause Analysis Technique (SCAT). Analisis menghasilkan sepuluh jenis tindakan pengendalian yang dapat dilakukan untuk mencegah terjadinya kecelakaan, terdiri dari 50\% tindakan teknis (desain) dan 50\% tindakan nonteknis. Sebagai tindakan kunci adalah penyediaan tenaga ahli keselamatan kerja untuk menginduksi tindakan pengendalian lainnya. Evaluasi manajemen menilai tindakan pengendalian kunci dapat diimplementasikan dalam jangka pendek.
\end{abstract}

Kata kunci: bahaya permesinan, investigasi, analisis penyebab, SCAT

\begin{abstract}
Machinery accident is common in many industries, including in palm oil industries. Machinery accident prevention is needed to avoid the impact of losses. Accident prevention due to machining can be done through an anticipation approach by learning from previous cases and taking control measures. Previous researches related to workplace accidents in the palm oil industries were more general to find the causes and control actions. The commonly used methods were work posture analysis, ergonomics evaluation, and hazard identification. This research focused on a case of occupational accident in capstan machine operator in the palm oil processing industry with fatal effect, which was death. So far there has been no research publication on accidents caused by this machine. The study was analytical descriptive by examining the case to find the root causes of the problem and provide a solution. The techniques used were 5 whys and Systematic Cause Analysis Technique (SCAT). The analysis resulted in ten types of control action that can be taken to prevent accidents, consisting of 50\% engineering control (design) and 50\% non-technical actions. The provision of occupational safety experts was identified as a key action control which will induce other control actions. Evaluation by management assessed that the key control action can be implemented immediately.
\end{abstract}

Keywords: machinery hazard, investigation, cause analysis, SCAT

\section{Pendahuluan}

Bahaya mesin (mechanical hazard) adalah bahaya-bahaya yang berhubungan dengan pengoperasian mesin dan peralatan, baik otomatis maupun manual [1]. Dalam kegiatan industri yang melibatkan mesin-mesin, potensi terjadinya bahaya ini cukup signifikan. Operasional mesin pada umumnya memiliki potensi sebagai penyebab cedera pada pekerja. Kecelakaan kerja akibat mesin (machinery accident) merupakan kejadian yang sering kali terjadi pada industri. Cedera yang diakibatkan dapat bervariasi dari tingkat minor atau cedera ringan sampai dengan cedera fatal termasuk kematian. Terdapat beragam sumber bahaya permesinan yang menjadi penyebab cedera pada pekerja. Sumber-sumber bahaya tersebut antara lain: perputaran mesin, gerak lawan arah, roda gigi, 
pisau, benda tajam, beban tekan, dan sejenisnya [2]. Jenis-jenis cedera akibat bahaya permesinan antara lain: remuk/hancur akibat himpitan (crushing), terjepit (shearing), terpotong (cutting), tertusuk (puncturing), serta kram dan keseleo (straining and spraining).

Pada kenyataannya kasus kecelakaan kerja akibat bahaya permesinan sering kali terjadi. Pada tahun 2007 AXA Insurance melaporkan bahwa satu dari empat kejadian kecelakaan di tempat kerja terjadi akibat mesin. Health Safety Executive (HSE) juga merangkum bahwa kecelakaan akibat mesin merupakan salah satu faktor penyebab yang umum selain faktor pekerja dan lingkungan kerja [3]. Oleh karena itu pencegahan kecelakaan kerja akibat permesinan perlu dikembangkan untuk mencegah dampak kerugian yang ditimbulkan.

Koalisi Buruh Sawit Indonesia (2018) menerbitkan lembar fakta terkait perlindungan buruh sawit Indonesia. Dinyatakan bahwa buruh sawit menghadapi beragam permasalahan kerja. Salah satu permasalahan yang menonjol terkait keselamatan dan kesehatan kerja. Buruh sawit Indonesia pada umumnya menghadapai permasalahan beban kerja berlebih, risiko kesehatan kerja karena kontak dengan bahan-bahan kimia, risiko cedera karena peralatan kerja, dan kurangnya pengawasan K3 perusahaan [4]. International Labour Organisation (ILO) dalam publikasinya menyebutkan bahwa cedera karena mesin merupakan salah satu potensi bahaya bagi pekerja industri kelapa sawit [5]. Penelitian terdahulu tentang keselamatan pekerja industri kelapa sawit lebih bersifat menyeluruh untuk mengenali dan mengendalikan risiko yang diterima pekerja. Metode yang digunakan antara lain dengan pengaturan waktu kerja, pengendalian ergonomi musculoskeletal [6], identifikasi bahaya, dan penilaian risiko [7].

Pada prinsipnya semua kecelakaan kerja potensial untuk dilakukan pencegahan. Pencegahan kecelakaan dan penyakit akibat kerja, termasuk kecelakaan akibat permesinan dapat dilakukan melalui pendekatan antisipasi bahaya dengan belajar dari kasus yang telah terjadi sebelumnya dan melakukan tindakan pengendalian [8]. Konsepnya adalah melakukan investigasi mendalam terhadap kasus kejadian kecelakaan kerja untuk mengidentifikasi sumber penyebabnya. Berdasarkan sumber penyebab yang teridentifikasi, dikembangkan tindakan pengendalian untuk mencegah kejadian yang sama terulang kembali di waktu mendatang [9].

Makalah ini menjelaskan tentang investigasi dan analisis penyebab kecelakaan kerja pada operator mesin di industri kelapa sawit. Studi dilakukan terhadap kasus kejadian kecelakaan kerja pada operator mesin kapstan di sebuah industri pengolahan kelapa sawit di Sumatra. Kecelakaan kerja yang dialami pekerja berakibat fatal yaitu kematian. Kasus tersebut bukan yang pertama terjadi. Kejadian serupa pernah terjadi sebelumnya dengan korban operator mesin dan berakibat kematian. Manfaat yang diperoleh dari hasil studi adalah dirumuskan tindakan pengendalian yang tepat untuk mencegah kecelakaan serupa terjadi lagi di kemudian hari.

\section{Metode Penelitian}

Penelitian yang dilakukan merupakan sebuah studi berdasarkan kasus nyata di suatu industri pengolahan kelapa sawit di Sumatera, Indonesia. Industri ini ditentukan sebagai tempat studi karena telah mengalami beberapa kejadian kecelakaan yang berakibat fatal pada pekerjanya. Objek studi adalah kecelakaan kerja yang terjadi di stasiun kerja loading ramp. Loading ramp merupakan tahapan untuk memasukkan kelapa sawit ke dalam lori untuk dilanjutkan ke tahap selanjutnya yaitu perebusan. Kecelakaan terjadi ketika operator mesin kapstan mengarahkan tali agar tidak keluar dari tempat penggulungan pada mesin untuk menarik lori bermuatan kelapa sawit. Mesin kapstan adalah mesin untuk menggulung atau mengulur tali tambatan lori. Kecelakaan tersebut berakibat fatal yaitu kematian. Studi yang dilakukan meliputi dua langkah utama yaitu investigasi dan analisis penyebab (cause analysis). Berdasarkan hasil investigasi dan analisis penyebab, ditentukan tindakan pengendalian yang tepat dengan mempertimbangkan keterkaitan antara tindakan dan instrumen interrelationship diagram. Sebagai tahap pendahuluan dilakukan pengumpulan data terkait kronologi kejadian kecelakaan kerja. Pengumpulan data dan fakta kejadian dilakukan dengan observasi, wawancara, dan dokumentasi.

Studi bersifat deskriptif analitis dengan menelaah kasus untuk menemukan akar masalah dan memberikan solusi. Teknik yang digunakan adalah 5 whys dan Sytematic Cause Analysis Technique (SCAT). Teknik bertanya 5 whys dikembangkan oleh Sakichi Toyoda, yang kemudian digunakan oleh perusahaan Toyota Motor Corporation. Menurut [9] teknik 5 whys merupakan suatu proses pengajuan pertanyaan secara terus menerus yang dilakukan sampai memperoleh pemecahan masalah yang efektif. Tidak terdapat tahapan yang terpaku dalam menggunakan teknik bertanya 5 whys sehingga tidak diharuskan memberi pertanyaan "mengapa" secara berulang sebanyak lima kali. Alasan penggunaan istilah 5 whys menurut Taichi Ohno dari Toyota adalah karena seseorang akan memahami penyebab terjadinya masalah apabila sudah mengajukan pertanyaan mengapa sebanyak lima kali. Pada aplikasinya jumlah pertanyaan disesuaikan dengan kebutuhan pengguna atau hingga pengguna telah menemukan akar penyebab dari hal yang diidentifikasi. Pertanyaan yang diberikan merupakan pertanyaan yang saling berhubungan dengan pertanyaan selanjutnya. 
SCAT merupakan metode sistematis untuk menentukan akar penyebab suatu kejadian [11]. Sistematika SCAT dinyatakan dalam bentuk diagram (SCAT chart) yang terdiri dari lima blok yaitu: (1) deskripsi kejadian; (2) penyebab umum kejadian; (3) penyebab langsung kejadian, terdiri dari unsafe act dan unsafe condition; (4) penyebab dasar, terdiri dari faktor individu (personal factors), faktor pekerjaan (job factors), dan faktor manajemen; dan (5) tindakan pengendalian. Struktur diagram SCAT berupa rangkaian serial dari lima blok tersebut seperti ditunjukkan pada Gambar 1. Blok terakhir dalam diagram SCAT adalah solusi yang merupakan tindakan pengendalian berdasarkan penyebab kecelakaan yang diidentifikasi dari blok-blok sebelumnya.

\section{Hasil dan Pembahasan}

\section{Laporan Investigasi}

Berikut ini adalah penjelasan kronologi kejadian kecelakaan. Kecelakaan kerja terjadi pukul 13.15 WIB di stasiun kerja loading ramp setelah istirahat shift pagi. Awal mula terjadinya kecelakaan kerja adalah operator mesin kapstan mengarahkan tali ke area penggulungan pada mesin. Tali yang berbahan nilon berguna untuk menarik lori sehingga lori yang bermuatan kelapa sawit dapat bergerak/berpindah. Operator melakukan pekerjaannya apabila ada perintah dari rekannya bahwa lori siap untuk dipindahkan. Pada saat korban melakukan pengendalian proses penggulungan tali didapati tali hampir keluar dari tempat penggulungan sehingga korban berusaha mengatur gulungan tali di mesin capstan. Pada saat melakukan hal tersebut, sarung tangan yang digunakan terjepit mesin. Korban langsung berinisiatif menarik kembali sarung tangannya, namun sarung tangan tidak dapat lagi dilepas karena mesin terus memutar dan tali pun terus terlilit. Disaat korban sibuk berusaha melepas sarung tangannya, terjadi kejadian lain yaitu kaki korban terlilit tali hingga tidak bisa dilepas. Hal ini terjadi karena tali yang terjuntai di lantai dekat kaki korban. Sementara tali melilit, korban berusaha memanggil rekan kerjanya namun rekan kerja korban tidak mendengar dikarenakan kebisingan dari suara yang dihasilkan proses perebusan dan boiler. Tali terus menjalar ke atas dan 'memakan' setengah badan korban hingga perut korban terkoyak dan menewaskan korban. Kronologi kejadian saat korban mengalami kecelakaan hingga dievakuasi ditunjukkan dalam bentuk timeline pada Gambar 2. Investigasi lebih lanjut dilakukan dengan teknik 5 whys berdasarkan wawancara dengan dua informan yaitu karyawan yang berada di sekitar korban saat kejadian berlangsung. Hasil investigasi ditunjukkan pada Tabel 1.

\section{Analisis SCAT}

Berdasarkan kronologi kejadian dan hasil wawancara 5 whys dilakukan investigasi lebih lanjut dan penentuan faktor penyebab kecelakaan serta mengembangkan tindakan pengendaliannya dengan metode SCAT. Diagram SCAT kasus yang ditinjau ditunjukkan pada Gambar 3. Blok 1, 2, dan 3 dari diagram SCAT dikembangkan berdasarkan hasil investigasi dan hasil wawancara 5 whys. Blok 4 diagram SCAT menunjukkan penyebab dasar kecelakaan dari faktor individu, faktor pekerjaan dan faktor manajemen. Berdasarkan setiap penyebab, dikembangkan bentuk tindakan pengendalian di blok 5 dengan menggunakan data pendukung dan bertukar pikiran dengan pihak manajemen perusahaan. Hasil analisis SCAT memberikan 10 jenis tindakan pengendalian sebagai solusi untuk pencegahan kejadian kecelakaan. Sepuluh tindakan pengendalian tersebut $50 \%$ merupakan tindakan teknis (B, C, D, E, I) dan 50\% merupakan tindakan nonteknis (A, F, G, H, J). Tindakan teknis maksudnya adalah tindakan yang berupa redesain mesin, alat atau fasilitas kerja, sedangkan tindakan nonteknis berkaitan dengan aspek manajerial dan organisasi K3 perusahaan.

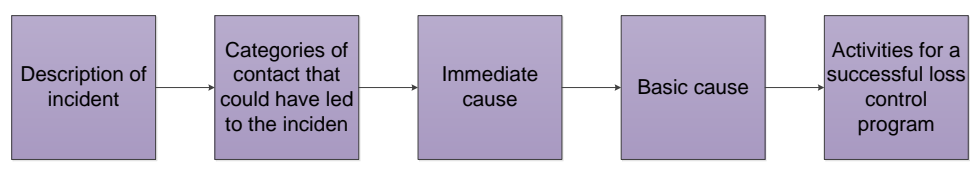

Gambar 1. Struktur diagram SCAT
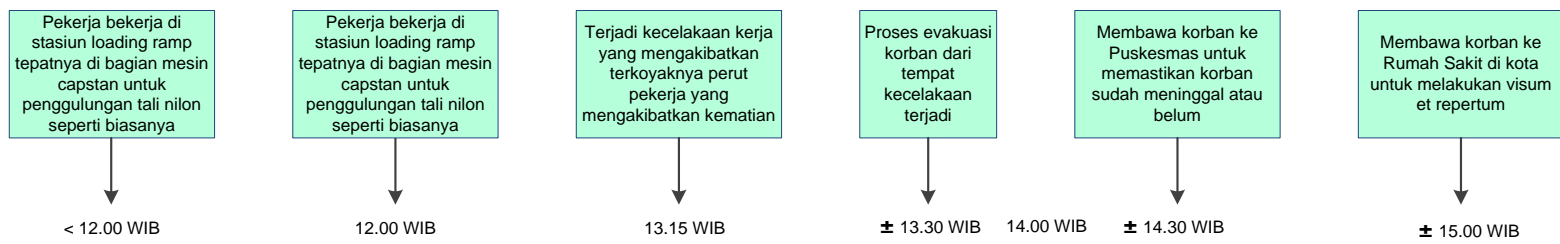

Keterangan:

pekerja akan berganti-gantian istirahat

Gambar 2. Timeline kejadian 
Tabel 1. Hasil wawancara 5 whys

\begin{tabular}{|c|c|c|}
\hline \multicolumn{3}{|c|}{ Sumber: informan \#1 } \\
\hline 1 & Mengapa korban melakukan kegiatan tersebut? & $\begin{array}{l}\text { Dikarenakan hal tersebut merupakan tugas dan } \\
\text { tanggung jawab korban }\end{array}$ \\
\hline 2 & $\begin{array}{l}\text { Mengapa tugas dan tanggungjawab tersebut } \\
\text { tetap dilakukan pada saat beristirahat? }\end{array}$ & $\begin{array}{l}\text { Dikarenakan pabrik mengolah secara berkelanjutan } \\
(24 \text { jam) }\end{array}$ \\
\hline 3 & Mengapa kecelakaan kerja dapat terjadi? & Hal tersebut diduga dikarenakan kelalaian pekerja \\
\hline 4 & Mengapa korban dapat lalai? & $\begin{array}{l}\text { Mungkin dikarenakan melamun atau banyak hal yang } \\
\text { kita tidak tau }\end{array}$ \\
\hline 5 & Mengapa korban tidak dapat diselamatkan? & $\begin{array}{l}\text { Dikarenakan tidak ada orang yang mendengar teriakan } \\
\text { dari korban }\end{array}$ \\
\hline 6 & Mengapa teriakan tidak terdengar? & Dikarenakan faktor kebisingan dipabrik \\
\hline 7 & Mengapa terjadi kebisingan? & $\begin{array}{l}\text { Dikarenakan lokasi terjadinya kecelakaan kerja dekat } \\
\text { dengan stasiun perebusan dan boiler yang } \\
\text { mengeluarkan suara cukup besar }\end{array}$ \\
\hline 8 & $\begin{array}{l}\text { Mengapa korban tidak menggunakan tombol } \\
\text { darurat untuk meminta pertolongan? }\end{array}$ & $\begin{array}{l}\text { Dikarenakan kondisi korban sudah tidak } \\
\text { memungkinkan menekan tombol darurat }\end{array}$ \\
\hline \multicolumn{3}{|c|}{ Sumber: informan \#2 } \\
\hline 1 & Mengapa korban tidak dapat diselamatkan? & Karena tidak ada yang menolong dengan segera \\
\hline 2 & $\begin{array}{l}\text { Mengapa rekan kerja korban tidak menolong } \\
\text { korban? }\end{array}$ & $\begin{array}{l}\text { Rekan kerja korban sedang sibuk dengan } \\
\text { tanggungjawab mereka masing-masing, dan juga } \\
\text { dikarenakan bising. }\end{array}$ \\
\hline 3 & Mengapa terjadi kebisingan? & $\begin{array}{l}\text { Karena dekat dengan stasiun perebusan dan stasiun } \\
\text { boiler, yang mengeluarkan uap sehingga } \\
\text { menghasilkan kebisingan. }\end{array}$ \\
\hline 4 & $\begin{array}{l}\text { Mengapa perusahaan tidak mengurangi } \\
\text { kebisingan? }\end{array}$ & $\begin{array}{l}\text { Tidak bisa, karena itu memang sudah menjadi risiko } \\
\text { perusahaan ketika membuka pabrik, pasti ada } \\
\text { kebisingan. }\end{array}$ \\
\hline
\end{tabular}

\section{Tindakan Pengendalian}

Proses sintesis dilakukan terhadap sepuluh jenis tindakan pengendalian hasil dari analisis SCAT. Proses yang dilakukan adalah penentuan tindakan kunci dan evaluasi seluruh tindakan pengendalian dari pihak manajemen. Penentuan tindakan kunci dengan menggunakan instrument interrelationship diagram. Ditelusuri keterkaitan antar tindakan satu dengan yang lain. Panah keluar dari suatu elemen berarti tindakan tersebut akan memberi pengaruh pada tindakan lainnya. Interrelationship diagram yang menghubungkan ke-sepuluh tindakan pengendalian ditunjukkan pada Gambar 4.

Dari interrelationship diagram diketahui bahwa tindakan pengendalian F (menyediakan ahli K3) merupakan elemen dengan panah ke luar yang paling banyak. Artinya tindakan pengendalian tersebut merupakan tindakan kunci yang akan menginduksi tindakan-tindakan lainnya. Sebagai tindakan kunci maka diusulkan sebagai prioritas implementasinya. Hal ini bukan berarti tindakan pengendalian yang lain menjadi tidak perlu dilakukan. Seluruh tindakan perlu dilakukan dengan memprioritaskan tidakan kunci untuk efektivitas dan efisiensinya.

Evaluasi terhadap tindakan pengendalian yang diusulkan dilakukan melalui mekanisme penilaian dari manajemen perusahaan. Tujuan evaluasi adalah untuk mengidentifikasi bagaimana perusahaan melakukan implementasi tindakan pengendalian yang diusulkan. Hasil evaluasi ditampilkan dalam bentuk matriks evaluasi yang ditunjukkan pada Tabel 2.

Hasil evaluasi manajemen menunjukkan beberapa tindakan sudah dilakukan oleh perusahaan sehingga perlu untuk dilanjutkan dan diperbaiki pelaksanaannya. Ada satu jenis tindakan yang dinilai manajemen untuk tidak dilakukan yaitu tindakan C (merancang kembali posisi tombol darurat pada mesin). Manajemen menilai relokasi tombol darurat pada mesin capstan sebenarnya tidak diperlukan karena posisinya pada mesin sudah ideal dan memenuhi standard ketentuan yaitu berada dalam jangkauan operator. Ada kekhawatiran dari pihak manajemen apabila dilakukan relokasi tombol darurat justru terjadi gangguan akibat proses produksi terhenti karena tidak ada mesin cadangan dan operator tidak terbiasa pada posisi yang baru sehingga akses justru lebih lama. Yang 
perlu dilakukan adalah memberi tanda pengingat yang jelas di area mesin serta pengarahan kontinyu pada operator tentang bekerja yang aman. Untuk tindakan kunci manajemen menilai dapat diimplementasikan dalam jangka pendek. Diharapkan dengan segera diimplementasikan tindakan kunci akan dapat menginduksi tindakan pengendalian lainnya.

Tabel 2. Matriks evaluasi tindakan pengendalian

\begin{tabular}{|c|c|c|c|}
\hline Kode. & Usulan Tindakan pengendalian & $\begin{array}{c}\text { Evaluasi } \\
\text { Implementasi }\end{array}$ & Penilaian manajemen \\
\hline A & Melakukan sosialiasi K3 & $\begin{array}{l}\text { Dapat di } \\
\text { impelementasikan }\end{array}$ & $\begin{array}{l}\text { Perusahaan telah melakukan sosialisasi, } \\
\text { seperti mengeluarkan surat edaran } \\
\text { penggunaan APD, surat SOP tentang } \\
\text { pengoperasian seluruh Stasiun yang ada di } \\
\text { perusahaan, serta memberikan pelatihan } \\
\text { tentang pemahaman K3 }\end{array}$ \\
\hline B & $\begin{array}{l}\text { Menyediakan alat khusus yang } \\
\text { untuk proses pengawasan } \\
\text { penggulungan tali }\end{array}$ & $\begin{array}{l}\text { Membutuhkan } \\
\text { pertimbangan }\end{array}$ & $\begin{array}{l}\text { Untuk mengadakan alat khusus ini mungkin } \\
\text { bisa dipertimbangkan, karena dikaitkan } \\
\text { dengan, bentuk alat seperti apa dan } \\
\text { ketersediaan anggaran perusahaan }\end{array}$ \\
\hline $\mathrm{C}$ & $\begin{array}{l}\text { Merancang kembali posisi tombol } \\
\text { darurat }\end{array}$ & $\begin{array}{l}\text { Tidak di } \\
\text { implementasikan }\end{array}$ & $\begin{array}{l}\text { Posisi tombol darurat sudah memenuhi } \\
\text { standar, hanya saja penandaan dan } \\
\text { pemberian pemahaman kepada operator } \\
\text { harus lebih intens }\end{array}$ \\
\hline $\mathrm{D}$ & $\begin{array}{l}\text { Melakukan tindakan } \\
\text { mengurangi kebisingan }\end{array}$ & $\begin{array}{l}\text { Membutuhkan } \\
\text { pertimbangan }\end{array}$ & $\begin{array}{l}\text { Untuk mengurangi kebisingan kemungkinan } \\
\text { akan sulit untuk dilakukan, yang bisa } \\
\text { dilakukan segera kemungkinan dengan } \\
\text { pemberian alat komunikasi seperti Walkie } \\
\text { Talkie dan disangkutkan di bahu, sehingga } \\
\text { apabila ada kejadian seperti ini cepat } \\
\text { diketahui }\end{array}$ \\
\hline $\mathrm{E}$ & $\begin{array}{l}\text { Merancang kembali tempat } \\
\text { penggulungan tali di mesin }\end{array}$ & $\begin{array}{l}\text { Dapat di } \\
\text { impelementasikan }\end{array}$ & $\begin{array}{l}\text { Tersedia komponen mesin untuk mengganti } \\
\text { tempat penggulungan tali yang lebih baik }\end{array}$ \\
\hline $\mathrm{F}$ & Menyediakan tenaga ahli K3 & $\begin{array}{l}\text { Dapat di } \\
\text { impelementasikan }\end{array}$ & $\begin{array}{l}\text { Saat ini di perusahaan telah menyiapkan } \\
\text { person sebagai Tenaga Ahli K3 sebanyak } 5 \\
\text { orang }\end{array}$ \\
\hline G & $\begin{array}{l}\text { Melakukan pengecekan dan } \\
\text { pengawasan rutin terkait K3 }\end{array}$ & $\begin{array}{l}\text { Dapat di } \\
\text { impelementasikan }\end{array}$ & $\begin{array}{l}\text { Perusahaan telah membentuk P2K3 untuk } \\
\text { dapat melaksanakan pengecekan dan } \\
\text { pengawasan rutin terkait K3 }\end{array}$ \\
\hline $\mathrm{H}$ & Melengkapi prosedur kerja & $\begin{array}{l}\text { Dapat di } \\
\text { impelementasikan }\end{array}$ & Sudah dilakukan \\
\hline I & $\begin{array}{l}\text { Menyediakan penutup untuk } \\
\text { mesin yang berputar }\end{array}$ & $\begin{array}{l}\text { Dapat di } \\
\text { impelementasikan }\end{array}$ & Sudah dilakukan \\
\hline $\mathrm{J}$ & $\begin{array}{l}\text { Melengkapi Alat } \begin{array}{l}\text { Pelindung } \\
\text { (APD) sesuai standar } \\
\text { dan } \\
\text { kebutuhan pekerja }\end{array} \\
\end{array}$ & $\begin{array}{l}\text { Dapat di } \\
\text { impelementasikan }\end{array}$ & Sudah dilakukan \\
\hline
\end{tabular}

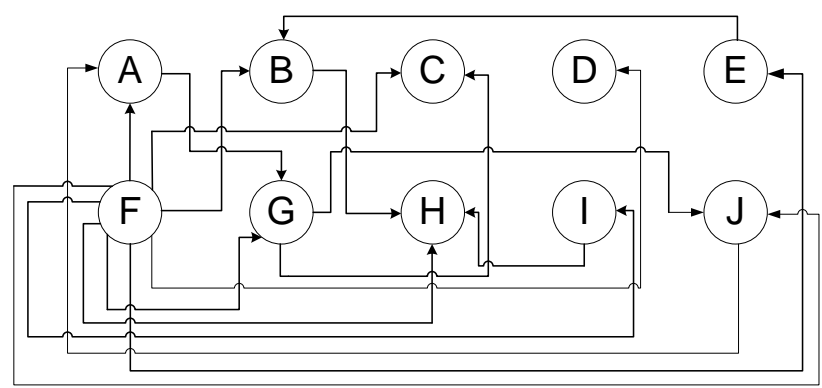

Gambar 4. Interrelationship diagram tindakan pengendalian 


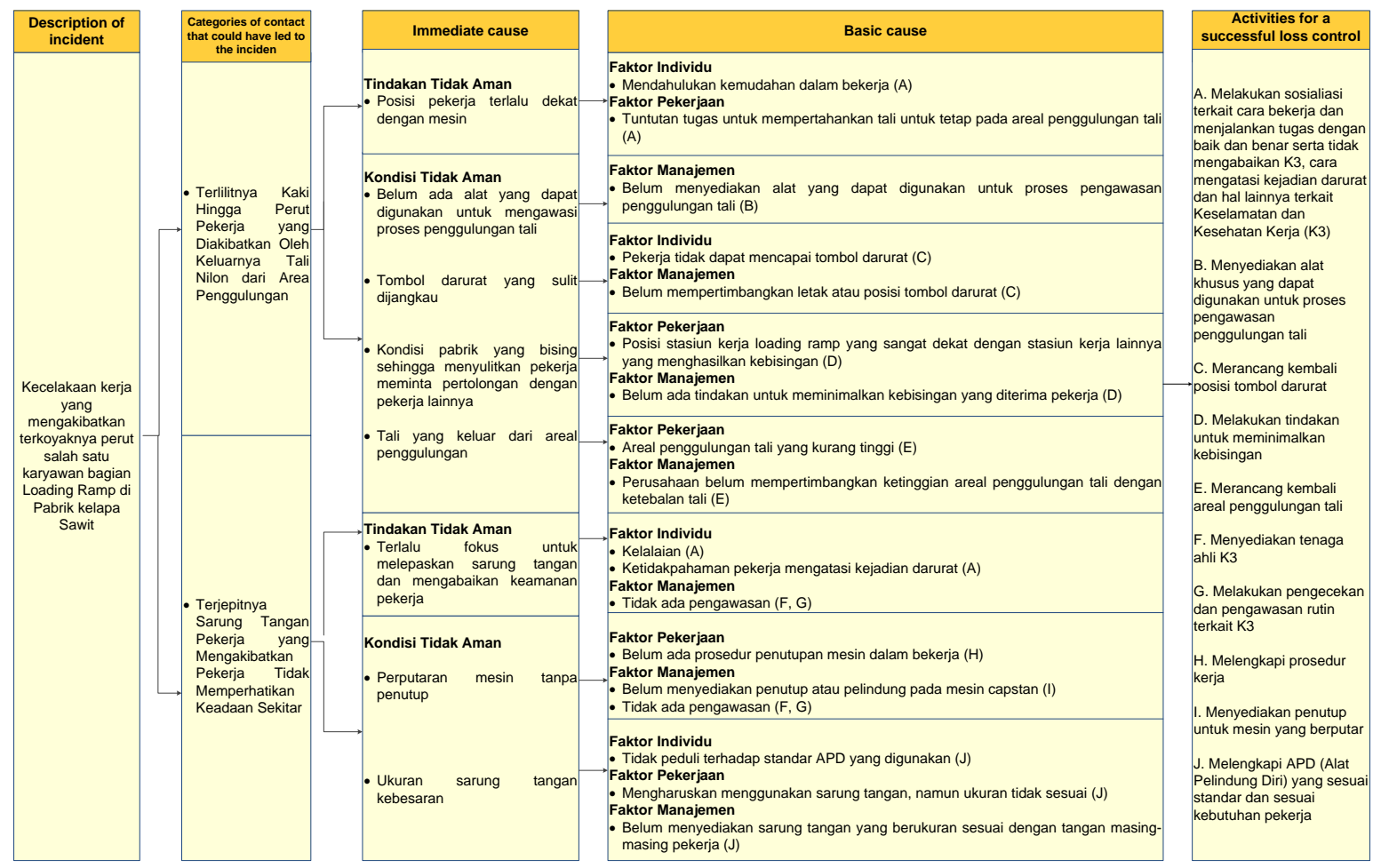

Gambar 3. Diagram SCAT kasus kecelakaan kerja

\section{Kesimpulan}

Studi terhadap kasus kecelakaan kerja operator mesin yang ditinjau menemukan penyebab dasar dari faktor individu, manajemen dan pekerjaan. Investigasi dengan metode SCAT menghasilkan sepuluh tindakan pengendalian berdasarkan penyebab kejadian. Kategori tindakan adalah 50\% merupakan pengendalian teknis dan 50\% merupakan pengendalian administratif/organisasional. Teridentifikasi tindakan pengendalian kunci adalah penyediaan tenaga ahli K3, maka diusulkan untuk diprioritaskan implementasinya. Evaluasi manajemen menilai tindakan pengendalian kunci dapat diimplementasikan dalam jangka pendek. Tindakan pengendalian kunci ini akan menginduksi tindakan pengendalian lainnya sehingga implementasi lebih efektif dan efisien. Hasil dari penelitian ini masih berupa konsep rancangan administratif tindakan pengendalian. Penelitian belum secara rinci meninjau aspek teknis permesinan terhadap desain mesin kapstan yang digunakan perusahaan.

Berdasarkan hasil analisis terhadap kasus kecelakaan kerja yang ditinjau, dimungkinkan penelitian lanjutannya. Analisis rinci untuk implementasi tindakan pengendalian teknis akan memberikan solusi bagi perusahaan untuk mencegah terjadinya kecelakaan serupa. Rancangan ulang tempat penggulungan tali pada mesin dan mereduksi kebisingan yang ditimbulkan mesin dengan pendekatan evaluasi desain mesin kapstan merupakan area penelitian lanjutan yang dapat dikembangkan dari hasil penelitian ini.

\section{Daftar Pustaka}

[1] C. R. Asfahl, Industrial safety and health management. New Jersey: Prentice Hall, 2004.

[2] D. L. Goetsch, Occupational safety and health for technologists, engineers, and managers, 8th edition, New Jersey: Prentice Hall, 2011.

[3] A. Gibb, S. Hide, R. Haslam, D. Gyi, S. Atkinson, \& R. Duff, "Construction tools and equipment - their influence on accident causality,". Journal of Engineering, Design and Technology, vol. 3 no. 1, hal.1223, 2005.

[4] Koalisi Buruh Sawit, Lembar fakta perlindungan buruh sawit Indonesia. Koalisi Buruh Sawit Indonesia, 2018.

[5] International Labor Organization, International programme on the elimination of child labour safety and health fact sheet hazardous child labour in agriculture oil palm. Geneva: ILO, 2004.

[6] Hendra \& S. Raharjo, "Risiko ergonomi dan keluhan musculoskeletal disorders (MSDs) pada pekerja panen kelapa sawit," Prosiding Seminar Nasional Ergonomi IX, 2009.

[7] F. Mallapiang \& I. A. Samosir, "Analisis potensi bahaya dan pengendaliannya dengan metode HIRAC," Al-Sihah: Public Health Science Journal, vol. IV, no. (2), hal. 350-362, 2014. 
[8] L. Haney, "A primer for effective accident investigation: reducing the toll on resources," $A A O H N$ Journal, vol. 51, no. 4, hal. 180-186, April 2003.

[9] M. F. O'Toole, "Investigating accidents: finding facts not faults," Super Vision, vol. 63, no. 7, July 2002.

[10] K. Jahja, Tantangan industri manufaktur. Jakarta: PT Temprint, 1994.

[11] A. D. Livingston, G. Jackson, \& K. Priestley, Root causes analysis: literature review. London: HSE Books, 2001. 